\title{
ENERGY EFFICIENCY OF NITROGEN FERTILIZATION IN DURUM WHEAT AND SORGHUM GRAINS

\author{
Galia Panayotova $^{1}$, Svetla Kostadinova ${ }^{2}$, Ivan Velinov ${ }^{3}$
}

\begin{abstract}
The objective of this study was to assess the energy efficiency of nitrogen fertilization in durum wheat and sorghum grains in the period 2017-2019. Bulgarian durum wheat variety Predel was studied at a stationary fertilizer trial on soil type Pellic vertisols at the Institute of Field Crops in Chirpan, Bulgaria. Grain sorghum hybrid EC Alize was investigated on the experimental field of the Agricultural University of Plovdiv, Bulgaria, on soil type Mollic Fluvisols. The crops were grown under non-irrigated conditions. The studied nitrogen rates were $0,60,120,180$, and $240 \mathrm{~kg} \mathrm{~N} . \mathrm{ha}^{-1}$. In durum wheat, nitrogen was applied two times: one third at sowing, and the rest - as top dressing in the tillering stage. In sorghum, the total nitrogen was applied as pre-sowing fertilization before sowing. The nitrogen fertilizer was applied as $\mathrm{NH}_{4} \mathrm{NO}_{3}$. The experimental design was a randomized, complete block design with four replications with a size of experimental plots of 20 $\mathrm{m}^{2}$ for both crops. The energy efficiency of nitrogen fertilization $(\eta)$ was calculated as the ratio between the received energy from additional grain yield of wheat and sorghum, respectively, and the invested energy from fertilization. It was established that energy efficiency of nitrogen fertilization depended on the nitrogen rate and hydro-thermal conditions during the vegetation period of durum wheat and sorghum. The bioenergy coefficient of durum wheat widely varied from $0.79\left(\mathrm{~N}_{240}\right.$ in 2018) to 4.44 ( $\mathrm{N}_{60}$ in 2017). The average for the period, the highest value of energy efficiency of nitrogen fertilization was obtained at the low rate $\mathrm{N}_{60}$ The higher nitrogen rate of $240 \mathrm{~kg} \mathrm{~N} \cdot \mathrm{ha}^{-1}$ was slightly effective. Under drought conditions during the vegetation period of sorghum, most effective was the application of rates $\mathrm{N}_{120}$ with the highest energy coefficient of 1.23. The application of $180 \mathrm{~kg} \mathrm{~N} \cdot \mathrm{ha}^{-1}$ to sorghum was the most energy efficient under the favorable hydro-thermal conditions in 2018 and 2019, and the average for the period 2017-2019. A low N60 rate in grain sorghum was inefficient from an energy point of view. Durum wheat showed higher energy efficiency of nitrogen fertilization compared to grain sorghum.
\end{abstract}

UDC Classification: 633.1, DOI: https://doi.org/10.12955/pns.v1.126

Keywords: energy efficiency, nitrogen, wheat, sorghum.

\section{Introduction}

The intensive agricultural technologies and increased yields are accompanied by an increase in the cost of non-renewable or exhaustible energy. One of the most important resources within agriculture is nitrogen $(\mathrm{N})$, and depletion of $\mathrm{N}$ resources is an important element in the evaluation of sustainability in agriculture. Energy is directly used in land preparation, tillage operations, sowing, irrigation, harvesting; and indirectly used in inputs such as seed, fertilizers, pesticides and irrigation water. The comparison of energy productivity of different crops can be used as an effective tool to prioritize crops planting in each area. The output energy is obtained in the form of feed, fodder, fruits, vegetables, seed and grain. Therefore, energy efficiency from fertilization needs to be taken into account in sustainable agriculture. Agricultural production efficiency is defined as the ratio between the amount of input energy, including $\mathrm{N}$ fertilizers and the energy contained in the obtained products. In an energy crop context, sustainability in crop production could aim at enhanced energy output with maintained or reduced depletion of $\mathrm{N}$ resources (Pourazaria et al., 2015). Crop energy accumulated in crops is estimated in mega joules (MJ) and reported in basic production, total production and additional production. The authors reported as the main components of the energy balance of field crop rotations the use of machinery, fuel, irrigation and fertilization, and recommended minimum treatments, lower fertilization rates, timely updating the machines and the use of renewable energy sources (Azarpour, 2012; Meyer-Aurich et al., 2012). The manufacture of mineral fertilizers, package, transport and usage occupy about $45 \%$ of the used energy in agriculture (Mudahar and Hignett, 1987). In this context, the used fertilizer is actually equivalent to the input energy in agricultural production. Nitrogen fertilization is a main cost of non-renewable energy sources in agriculture and in terms of insufficient energy resources it is important to find ways to increase its energy efficiency (Hosseinpanahi and Kafi, 2012). A significant increase of grain yield was achieved through the use of both new cultivars and the input of a larger amount of energy in the form of fertilizers, mechanization and pesticides (Faidley, 1992). According to Piringer (2006) in the total energy input of US grown wheat, the share of only

\footnotetext{
${ }^{1}$ Trakia University, Faculty of Agriculture, Department of Plant Production, Stara Zagora, Bulgaria, galia_panayotova@abv.bg

${ }_{2}^{2}$ Agricultural University, Faculty of Agronomy, Department of Agrochemistry and Soil Science, Plovdiv, Bulgaria, svetlak@au-plovdiv.bg

${ }^{3}$ Agricultural University, Faculty of Agronomy, Department of Agrochemistry and Soil Science, Plovdiv, Bulgaria, van211@abv.bg
} 
nitrogenous fertilizer was $47 \%$, whereas in a study of Australia, the share of all fertilizers (i.e. nitrogen, phosphorus, and potash) was $47 \%$.

According to various sources the specific energy content in $\mathrm{N}$ fertilizers is $58-90 \mathrm{MJ}$ per $\mathrm{kg} \mathrm{N}$, in phosphorus is $44 \mathrm{MJ}$ per $\mathrm{kg} \mathrm{P}_{2} \mathrm{O}_{5}$ and in potassium - $2.27 \mathrm{MJ}$ per $\mathrm{kg} \mathrm{K}_{2} \mathrm{O}$ (Mineev, 2004). The efficiency of agriculture productivity is defined as the correlation between the amount of input energy (which could be in the form of $\mathrm{N}$ or other fertilizers) and the energy of production (Hulsbergen et al., 1997).

Considerable research has been conducted on the energy use pattern of field crops under different management practices in the world. Most of the work related to the energy use pattern for different crops was for wheat (Mirasi et al., 2014; Moghimi et al., 2013) and cotton (Zahedi et al., 2014). The results of long-term studies in Iran show that nearly $80 \%$ of the consumer energy in Iran's agriculture is non-renewable (Beheshti et al., 2010). According to Glogova (2013) the highest energy yield for sugar and popcorn maize is realized with the use of fertilizer rate $\mathrm{N}_{220} \mathrm{P}_{100} \mathrm{~K}_{80}$ and in comparison with the control $\mathrm{N}_{0} \mathrm{P}_{0} \mathrm{~K}_{0}$ in the same fertilizer rate the effect of fertilizers is the highest, $35 \%$ by sugar maize and $23 \%$ by popcorn maize.

Ozkan et al. (2004) reported that animal manures have more effective nutritional effects than chemical fertilizers and also their production requires less energy consumption, so that the consumption of one ton of animal manure equals to only $300 \mathrm{MJ} \mathrm{ha}^{1}$ which is equivalent to only $5 \mathrm{~kg} \mathrm{~N}$ fertilizer. So theconsumption of fertilizers with natural origin helps to much reduce the energy consumption in the production system and increase its productivity.

The most common biomass production includes corn, wheat, sugarcane, sugar beet, and sweet sorghum (López-Sandin et al., 2018; Vermerris \& Saballos, 2013). However, yields vary according to variety, cultivation conditions (soil, water, climate, pests, and diseases), inputs, and agronomic practices (Mishra et al., 2017). In comparison with other crops, yield has a lower use of inputs due to the favorable combination of its agronomic and technological characteristics, making it one of the best raw materials in the production of sugar and biofuels (Bonin et al., 2016).

In Bulgaria, the energy efficiency of nitrogen was studied only for some field crops (Kostadinova and Yordanova, 2010; Kostadinova et al., 2010; Rachovski et al., 2010). There are no studies for grain sorghum and for durum wheat.

The negative effects associated with increased energy production may be mitigated if renewable energy sources are employed and increased efficiency of the related production processes is attained, so that energy consumption decreases without affecting quality of life (Rocha et al., 2018).

The aim of this research was to study the energy efficiency of nitrogen fertilization in sorghum and durum wheat grains and to establish in which crop nitrogen fertilization leads to higher energy efficiency. The results are discussed in an agricultural sustainability perspective.

\section{Data and methodology}

The investigation was carried out in Southern Bulgaria in 2017-2019 under non-irrigated conditions. The experimental design for sorghum and durum wheat was a randomized, complete block design with four replications with a size of experimental plots of $20 \mathrm{~m}^{2}$. The rates of applied nitrogen fertilization as $\mathrm{NH}_{4} \mathrm{NO}_{3}$ for both crops were $0,60,120180$ and $240 \mathrm{~kg}^{-\mathrm{ha}^{-1}}$. The nitrogen fertilization was on the background $\mathrm{P}_{50} \mathrm{~K}_{50}$ fertilization as triple superphosphate and potassium chloride, respectively. Standard farming practices for both crops for the region of Southern Bulgaria were applied.

The investigation on the_sorghum hybrid EC Alize was carried out on the experimental field of the Agricultural University of Plovdiv. The predecessor was wheat. Total nitrogen was applied presowing. The soil type of the experimental field is alluvial-meadow Mollic Fluvisols (FAO, 2006) with a slightly alkaline reaction $\mathrm{pH}_{\mathrm{H} 2 \mathrm{O}}=7.80$. The content of available nutrients in the soil before sowing of

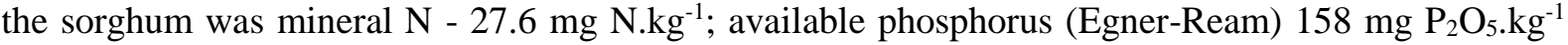
and exchangeable potassium $210 \mathrm{mg} \mathrm{K}_{2} \mathrm{O}_{\mathrm{kg}} \mathrm{k}^{-1}$.

The investigation on durum wheat was also carried out on the testing field of the Field Crop Institute, Chirpan, near Plovdiv, at cotton-durum wheat crop rotation. Nitrogen was applied two times $-1 / 3$ presowing and $2 / 3$ as early spring dressing. The soil was Pellic Vertisols (FAO, 2006). Soil analysis 
before the experiment indicated sorbcium capacity - 35-50 mequ /100g soil; bulk weight $-1.1-1.2$ g.cm ${ }^{-3}$; specific gravity - 2.6-2.7; organic matter - 2.0-2.4; mineral N $-30-35 \mathrm{mg} \mathrm{N} . \mathrm{kg}^{-1}$; available phosphorus and potassium - 70-90 mg $\mathrm{P}_{2} \mathrm{O}_{5} \cdot \mathrm{kg}^{-1}$ and 240-280 $\mathrm{mg} \mathrm{K}_{2} \mathrm{O} \cdot \mathrm{kg}^{-1}$, respectively.

The values of temperature and precipitations during the vegetation period characterized the hydrothermal conditions of 2017 as warm and dry. In contrast, the months of May, June and July of 2018 were very humid. The amount of precipitation exceeded nearly twice the values of the long-term norm. The conditions during the vegetation of 2019 were similar to those in 2018.

The energetical efficiency of fertilization was defined by the use of the following indexes (Mineev, 2004):

1. The amount of stored energy in the main agricultural production resulting from fertilization: $E=$

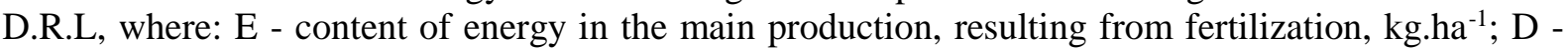
additional yield from main production as a result of fertilization, $\mathrm{kg} \cdot \mathrm{ha}^{-1}$; $\mathrm{R}$ - coefficient of reestimation of an agricultural production unit to dry matter; L - content of total energy in $1 \mathrm{~kg}$ dry matter from the main production, MJ. The values of parameters $\mathrm{L}$ and $\mathrm{R}$ for durum wheat are respectively $19.13 \mathrm{MJ}$ and 0.86 , and for sorghum - $18.34 \mathrm{MJ}$ and 0.86 .

2. The consumption of energy (A) of the nitrogen fertilizers input: $A=R_{N} \times 86.6$, (MJ.ha ${ }^{-1}$ ), where $R_{N}$ is the nitrogen rates in a $\mathrm{kg}$ of active matter per hectare. The amounts of energy for nitrogen is 86,6 (MJ for $1 \mathrm{~kg}$ active matter).

3. The energy efficiency of the $\mathrm{N}$ fertilizers used $(\eta): \eta=E / A$, where: $\eta$ - energetical efficiency (energy use efficiency); $\mathrm{E}$ - amount of energy, received in the additional main production by input of $\mathrm{N}$ in MJ; A - consumed energy for input nitrogen fertilizers, MJ.

For a statistical estimation of fertilization energy efficiency $(\eta)$ a test analysis of variance by Duncan (1955) at $\mathrm{P}<0.05$ was used.

\section{Results and Discussion}

The amount of additional yield of durum wheat and sorghum grain resulting from the applied nitrogen fertilization of $60,120,180$ and $240 \mathrm{~kg} \mathrm{~N} \cdot \mathrm{ha}^{-1}$ depends on the weather conditions during the growing season of the two crops.

The lowest additional average yield of $1198 \mathrm{~kg} \cdot \mathrm{ha}^{-1}$ of durum wheat was obtained in 2018 (Table 1). The average additional yield of wheat in 2017 and 2018 was higher by $26.7 \%$ and $50.1 \%$, respectively. Nitrogen fertilization increased the additional wheat grain yield to the low rate $\mathrm{N}_{60}$. The only exception to this dependence was observed in the high fertilization rate $\mathrm{N}_{240}$ in 2017, when $16.1 \%$ lower_additional wheat grain yield was obtained. Nitrogen fertilization on durum wheat at a rate of 180 $\mathrm{kg} \mathrm{N} \cdot \mathrm{ha}^{-1}$ resulted in the highest additional grain yield in $2018-1700 \mathrm{~kg} \cdot \mathrm{ha}^{-1}$ and in $2019-2450 \mathrm{~kg} . \mathrm{ha}^{-}$ 1. The additional yield at this rate, average for the study period, was by $89.6,19.3$ and $39.8 \%$ more than the additional yield obtained at fertilization with $\mathrm{N}_{60}, \mathrm{~N}_{120}$ and $\mathrm{N}_{240}$, respectively.

Table 1: Additional grain yield and energy in additional grain yield of durum wheat depending on nitrogen fertilization

\begin{tabular}{|c|c|c|c|c|}
\hline Fertilization $\quad$ Year & 2017 & 2018 & 2019 & $2017-2019$ \\
\hline \multicolumn{5}{|c|}{ Additional grain yield, kg. ha $^{-1}$} \\
\hline $\mathrm{N}_{60}$ & 1370 & 790 & 930 & 1030 \\
\hline $\mathrm{N}_{120}$ & 1840 & 1300 & 1770 & 1637 \\
\hline $\mathrm{N}_{180}$ & 1710 & 1700 & 2450 & 1953 \\
\hline $\mathrm{N}_{240}$ & 1150 & 1000 & 2040 & 1397 \\
\hline Average & 1518 & 1198 & 1798 & \\
\hline \multicolumn{5}{|c|}{ Energy in additional grain yield, MJ.ha ${ }^{-1}$} \\
\hline $\mathrm{N}_{60}$ & 22539 & 12997 & 15300 & 16945 \\
\hline $\mathrm{N}_{120}$ & 30271 & 21387 & 29120 & 26926 \\
\hline $\mathrm{N}_{180}$ & 28133 & 27968 & 40307 & 32136 \\
\hline $\mathrm{N}_{240}$ & 18920 & 16452 & 33562 & 22978 \\
\hline Average & 24966 & 19701 & 29572 & \\
\hline
\end{tabular}

Source: Authors 
The energy in the additional grain yield follows the pattern of the amount of additional yield resulting from the applied nitrogen fertilization of wheat and the influence of weather conditions during the growing season. The lowest energy in the additional grain yield of wheat - 12997 MJ.ha ${ }^{-1}$ was found to be obtained by fertilization with $\mathrm{N}_{60}$ in 2018 and the highest - $40307 \mathrm{MJ} \cdot \mathrm{ha}^{-1}$ at $\mathrm{N}_{180}$ in 2019. On an average of three years, the greatest amount of energy in the additional grain yield was obtained at the rate of $\mathrm{N}_{180}$. The high nitrogen rates $\mathrm{N}_{240}$ reduced the amount of energy in the additional grain yield of durum wheat by $28.5 \%$ on average compared to fertilization with $\mathrm{N}_{180}$. Results of Ziaei et al. (2015) showed that total energy inputs of wheat fields of all agricultural activities were $32492 \mathrm{MJ}^{-h^{-1}}{ }^{-1}$. Total energy outputs for wheat and barley fields were 48517 and $49801 \mathrm{MJ} \mathrm{ha}^{-1}$, respectively. Based on these results the amount of energy use efficiency for wheat fields were 1.49, and the amount of energy productivity were 0.056 . The results of Jadida et al. (2012) revealed that wheat production consumed a total of $37694.6 \mathrm{MJ} /$ ha of which fertilizers was $52.8 \%$, followed by diesel fuel (15.3\%).

The amount of additional grain obtained from sorghum had the lowest average value in 2017 due to very dry conditions during the vegetation of plants (Table 2). The favorable weather conditions during the vegetation period of 2018 and 2019 led to a higher average additional yield by $62.9 \%$ and $33.7 \%$, respectively, compared to 2017. The lowest additional grain yield of sorghum in the range $270-420$ $\mathrm{kg} \cdot \mathrm{ha}^{-1}$ was obtained at the low nitrogen levels of $\mathrm{N}_{60}$. Sorghum reacted very positively to nitrogen fertilization. The average for the period, the application of rates $\mathrm{N}_{180}$ and $\mathrm{N}_{240}$ increased the amount of additional yield by $4.33-4.41$ times compared to rate $\mathrm{N}_{60}$. With sorghum, the lowest and highest energy values of the additional yield were obtained at fertilization with $60 \mathrm{~kg} \mathrm{~N}$.ha' ${ }^{-1}$ in 2019 (4260 MJ.ha ${ }^{-1}$ ) and $\mathrm{N}_{240}$ in 2018. The resulting energy in additional yield was higher in all variants of nitrogen fertilization in 2018, which was characterized by more rainfall during the growing season of sorghum. On average, over the three-year experimental period, the highest amount of energy in the additional grain yield was $23661 \mathrm{MJ} \cdot \mathrm{ha}^{-1}$ - obtained at the high rate $\mathrm{N}_{240}$. Our results corroborated that the $\mathrm{N}$ level and the year of cultivation exerted important effects on durum wheat and sorghum grain production.

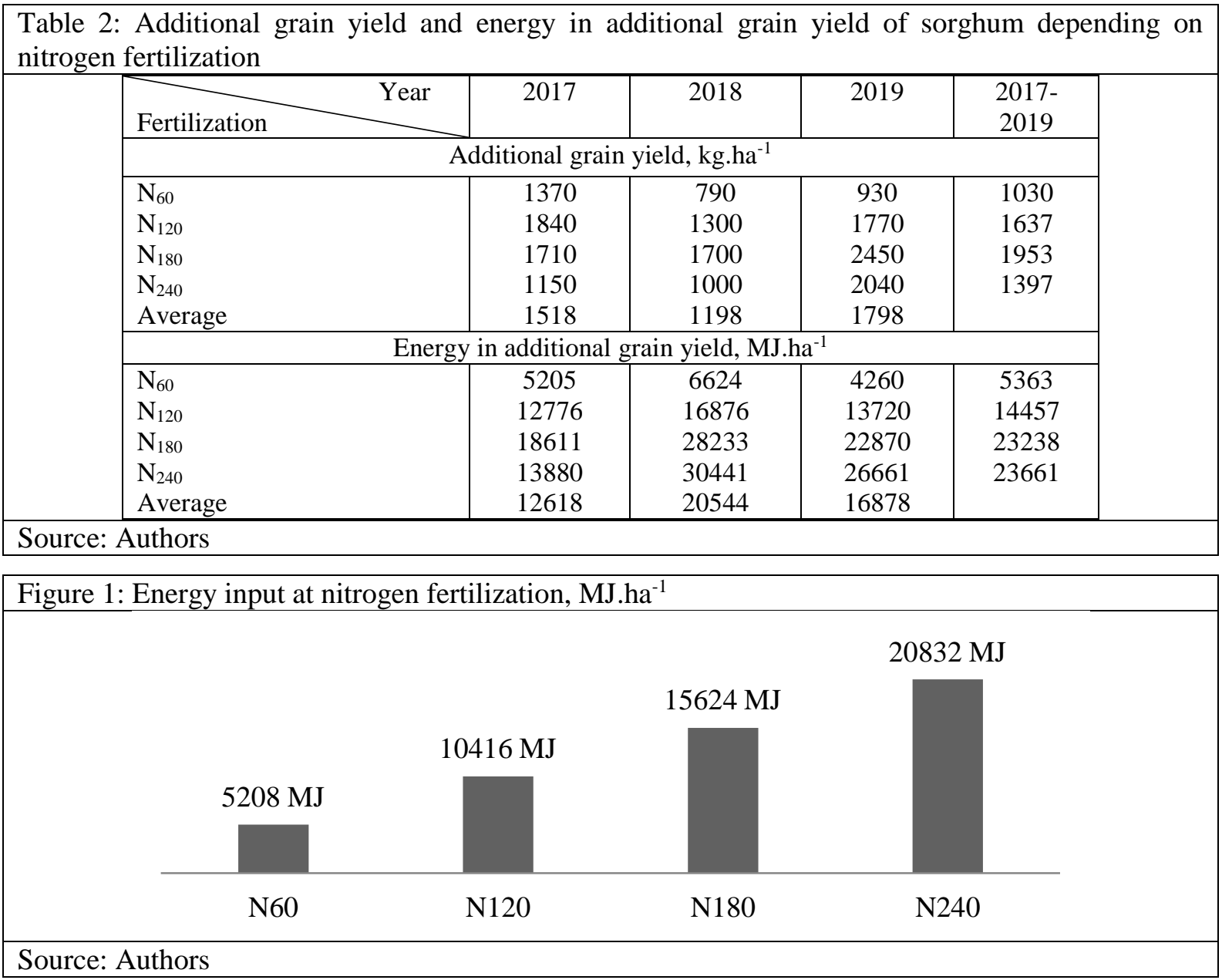


Cabrera-Ariza et al. (2019 and Díaz et al. (2018) reported that crop management had important effects on sorghum energy balance. The energy produced varied between 126 and $365 \mathrm{GJ}^{\text {ha }}{ }^{-1}$ depending on crop management, hybrid and growing season.

The amount of fertilizer energy input increased in parallel with the value of nitrogen rate (Figure 1).

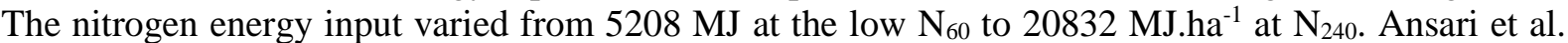

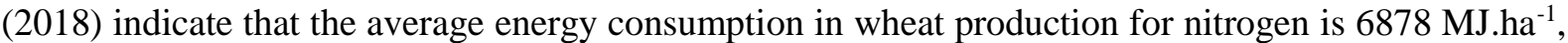
which is lower than the received our results.

The energy efficiency of nitrogen fertilization in durum wheat and sorghum varied depending on the amount of incorporated nitrogen and the energy produced in the additional grain yield (Table 3).

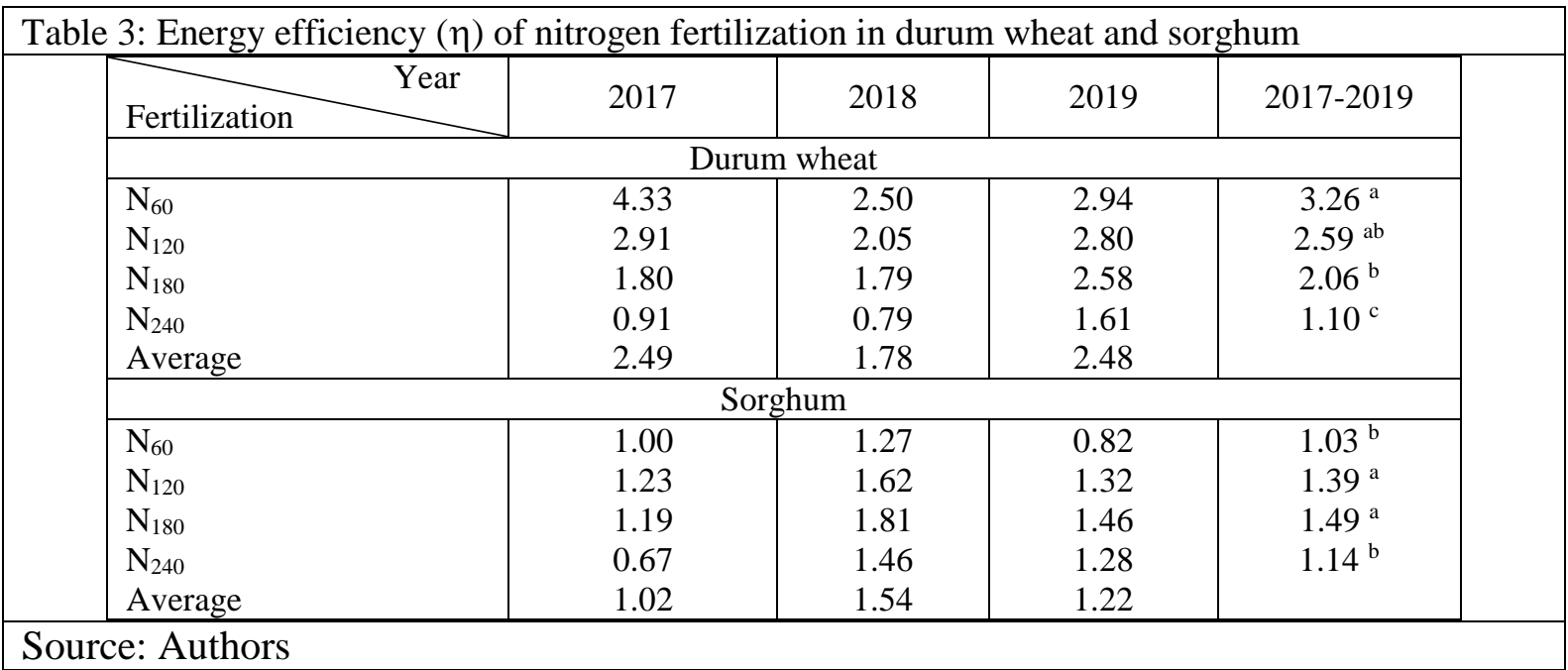

The energy efficiency of nitrogen fertilization in durum wheat decreased with the increase in the amount of applied nitrogen fertilizer. On average, the use of $\mathrm{N}_{120}, \mathrm{~N}_{180}$ and $\mathrm{N}_{240}$ reduced the energy efficiency of fertilization by $20.6,36.8$ and $66.3 \%$ respectively, compared to $\mathrm{N}_{60}$. The application of increased rate $\mathrm{N}_{240}$ in 2017 and 2018 was not an effective agronomic activity from an energy point of view, due to the values of energy efficiency $(\eta)$ lower than one, which indicated that the energy in the additional grain yield was less than the energy input from nitrogen fertilization. From an energy point of view, durum wheat had effective low to moderate nitrogen fertilization. At rates $\mathrm{N}_{60-120}$ the values of coefficient $\eta$ ranged within $2.05-4.33$.

The energy efficiency of nitrogen fertilization in sorghum varied within a narrower range compared to durum wheat. The bioenergy coefficient ( $\mathrm{y}$ ) over the experimental period of three years ranged from $0.67\left(\mathrm{~N}_{240}\right.$ in 2017) to 1.81 units $\left(\mathrm{N}_{180}\right.$ in 2018). The severe drought during the sorghum growing period in 2017 reduced the energy efficiency of nitrogen fertilization at the studied rates $\mathrm{N}_{60-240}$. Fertilization of sorghum at rates $\mathrm{N}_{120}$ and $\mathrm{N}_{180}$ had a high significant energy effect and values of 1.39 and 1.49 of bioenergy coefficient $\eta$. Low energy efficiency was found at $\mathrm{N}_{240}$. This high rate decreased the energy efficiency of fertilization and its application to sorghum is not suitable in terms of energy.

According to Pourazaria et al. (2015) in Central Sweden the N uptake efficiency and yield-specific N efficiency were higher in maize than wheat and ley. The yield $\mathrm{N}$ concentration was higher in the perennial ley than the annual crops, and lowest in maize. Energy output per $\mathrm{N}$ lost in the harvested product was greater in maize compared to wheat and ley. Khan et al. (2010) found that energy efficiency was higher in wheat crop (9.21) compared to rice (6.70) and barley where it was 8.21. Piringer (2006) points out that the benefit-cost ratio remained the highest on rice crop (3.33) compared to wheat (2.82) and barley (2.50). Uhr \&Vasileva (2015) indicated that maximum parameters of gross energy yield of wheat grain yields were reported at fertilization with $0.18 \mathrm{t} / \mathrm{ha}$ fertilizer nitrogen in cereal predecessor and $0.06 \mathrm{t} / \mathrm{ha}$ after cereal, and increasing the fertilizer rate of $0.0 \mathrm{t} / \mathrm{ha}$ to $0.18 \mathrm{t} / \mathrm{ha}$ nitrogen reduced the difference in the gross energy productivity of legume crops. In the case of Turkey the study showed that the inputs used in agricultural production were not used efficiently and led to many environmental problems (Canakci et al., 2005; Hatirli et al., 2005; Kardoni et al., 2015). Hence, they suggested that sustainable agriculture should be extended, and conscious farming should be 
provided. According to the report by Moore (2010) to achieve a sustainable system of food production, the amount of energy efficiency and the share of renewable energies should be increased in agricultural systems. A high consumption of non-renewable energies will reduce the energy use efficiency in production systems, because the production of chemicals and the use of machinery as the main index of common systems require large amounts of energy consumption.

\section{Conclusions}

The results of this study indicate that energy efficiency of fertilization is dependent on the nitrogen rate and weather conditions during the vegetation period of durum wheat and sorghum. The energy input from nitrogen fertilization should be reduced to increase energy efficiency of durum wheat and sorghum production. The highest value of energy efficiency of nitrogen for durum wheat was obtained at the low rate $\mathrm{N}_{60}$ and with sorghum most effective was the application of rates $\mathrm{N}_{120}$. The higher nitrogen rate of $240 \mathrm{~kg} . \mathrm{ha}^{-1}$ was slightly effective. Durum wheat showed higher energy efficiency of nitrogen fertilization compared to grain sorghum. The results are discussed in an agricultural sustainability perspective.

\section{References}

Ansari R., Liaqat, M. U., Khan H. I. \& Mushtaq, S. (2018). Energy Efficiency Analysis of Wheat Crop under Different Climate- and Soil-Based Irrigation Schedules. Proceedings 2018, 2, 184, 1-7, www.mdpi.com/journal/proceedings. doi:10.3390/ecws-2-04953.

Azarpour E. (2012). Determination of energy balance and energy indices in wheat production under watered farming in north of Iran. Journal of Agricultural and Biological Science, 7, 250-255.

Beheshti Tabar, I., Keyhani, A. \& Rafiee, S.H. (2010). Energy balance in Iran's agronomy (1990-2006). Renewable and Sustainable Energy Review, 14, 849-855.

Bonin, C.L., Heaton, E.A., Cogdill, T.J. \& Moore, K.J. (2016). Management of sweet sorghum for biomass production. Sugar Tech., 18, 150-159.

Cabrera-Ariza, A. M., Tozzini, C., Espinoza-Meza, S.E., Santelices-Moya, R.E., Magni- Canakci, M., Topakci, M., Akinci, I. \& Ozmerzi, A. (2005). Energy use pattern of some field crops and vegetable production: case study for Antalya region, Turkey. Energy Convers Manage, 46, 655-66.

Díaz, C.R. \& Alonso-Valdés, M.F. (2018). Effect of crop management intensity on energy and carbon dioxide balance of two bioenergy Sorghum bicolor hybrids. Italian Journal of Agronomy, 14(1), 26-33. https://doi.org/10.4081/ija.2018.1316.

Glogova L. (2013). Comparing energy yield and bioenergical coefficient of hybrids sugar and popcorn maize grown at different levels of fertilization. Science and Technologies, III, 224-227 (Bg)

Duncan, D.B. (1955). Multiple range and multiple F- test, Biometrics, 11.

Faidley, L.W. (1992). Energy and Agriculture, In: R.C. Fluck (Editor), Energy in World Agriculture Vol. 6, Elsevier Science Publishers B.V. Amsterdam, The Netherlands, 1-12.

FAO (2006). Guidelines for Soil Description. Rome: FAO.

Hatirli, S.A., Ozkan, B. \& Fert, C. (2005). An econometric analysis of energy input-output in Turkish agriculture. Renewable and Sustainable Energy, Reviews, 9, 608-623.

Hosseinpanahi, F. \& Kafi, M. (2012). Assess the energy budget in farm production and productivity of potato (Solanum tuberosum L.) in Kurdistan, case study: Plain Dehgolan. Journal of Agroecology, 4, 159-169.

Hülsbergen, K. J. \& Klark, W. D. (1997). Stoff- und Energiebilanzen im Dauerfeldversuch, In: Produktionspotentiale in der Landnutzung, Wiss. Beitrage der 5, Hochschultagung der Landwirtschaftlichen Fakultat der Universitat Halle, 192-200.

Jadida, S., Homayounifar, M., Sabuni, M. \& Mohammadi, A. (2012). Energy analysis and optimization of inputs for wheat production in Marand region. Indian Journal of Agricultural Sciences 82 (2), 21-24.

Kardoni F., Ahmadi, M. Jami-Al \& Bakhshi M.R. (2015). Energy Efficiency Analysis and Modeling the Relationship between Energy Inputs and Wheat Yield in Iran, 2015. International Journal of Agricultural Management and Development, 5(4), 321-330.

Khan S., Khan M.A. \& Latif N. (2010). Energy requirements and economic analysis of wheat, rice and barley production in Australia. Soil \& Environ., 29 (1), 61-68.

Kostadinova, S. \& Yordanova, N. (2010). Fertilization and Energetic Efficiency at Barley variety Kamenica. Field Crops Studies, Vol. VI(1), 91-96.

Kostadinova S., Yordanova, N. \& Rachovski, G. (2010). Fertilization and Agronomic Efficiency at Barley variety Kamenica. Field Crops Studies, Vol. VI(1), 85-90.

López-Sandin I, Gutiérrez-Soto G., Gutiérrez-Díez A., Medina-Herrera N., Gutiérrez-Castorena E. \& Zavala-García, Fr. (2019). Evaluation of the Use of Energy in the Production of Sweet Sorghum (Sorghum Bicolor L.) under Different Production Systems. Energies, https://www.researchgate.net/publication/332899599.

Meyer-Aurich A, Ziegler T, Jubaer H, Scholz L \& Dalgaard T. (2012). Implications of energy efficiency measures in wheat production, Journal Energy, biomass and biological residues. International Conference of Agricultural Engineering - CIGR- 
AgEng 2012: Agriculture and Engineering for a Healthier Life, Valencia, Spain, 8-12 July 2012, pp. C-0700 http://www.cirg.ageng2012.org/images/fotosg/tabla_137_C0700.pdf.

Mirasi, A., Mousarrezasamadi, K.E. \& Taghipoor, M.B. (2014). An assessment of energy efficiency for wheat production in Iran. Elixir Agriculture, 72, 25440-25444.

Mineev, V. (2004). Agrochemistry, University of Moscow, 710-714.

Mishra, J.S., Kumar, R. \& Rao, S.S. (2017). Performance of sweet sorghum (Sorghum bicolor) cultivars as a source of green fodder under varying levels of nitrogen in semi-arid tropical India. Sugar Tech., 19, 532-538.

Moghimi, M. R., Alasti, B.M., Drafshi, M.A.H., Ghadim, M.A. \& Taki, M. (2013). Energy consumption and assessment of econometric model between input and output for wheat production in Gorve country, Kordestan Province of Iran. Intl J Agri Crop Sci. Vol. 5 (19), 2297-2302.

Moore, S.R. (2010). Energy efficiency in small-scale biointensive organic onion production in Pennsylvania, USA. Renewable Agriculture and Food System 25, 181-188.

Mudahar, M.S. \& Hignett, T.P. (1987). Fertilizer and Energy Use, In: Z.R. Helsel (Editor) Energy in Plant Nutrition and Pest Control, Vol. 2, 1-23.

Ozkan, B., Akcaoz, H. \& Fert, C. (2004). Energy input-output analysis in Turkish agriculture. Renewable Energy 29, 2939 2951.

Pourazaria, F., Vicoa, G., Båtha, B. \& Weiha M. (2015). Nitrogen use efficiency and energy harvest in wheat, maize and grassland ley used for biofuel - implications for sustainability. Procedia Environmental Sciences, 29, 22-23.

Piringer, G. (2006). Re-evaluation of energy use in wheat production in the Unites States. Journal of Industrial Ecology 10(12), 149-167.

Rachovski, G., Kostadinova, S., Manolov, I. \& Yordanova, N. (2010). Fifth years long-term fertilizing experiment of Agricultural University - Plovdiv, Agricultural University - Plovdiv, Scientific Works, vol. LV, book 1, 93-104 (Bg).

Rocha, A., Araújo, A., Carvalho, A. \& Sepulveda, J.A. (2018). New Approach for Real Time Train Energy Effciency Optimization. Energies, 11, 2660.

Uhr Z. \& Vasileva, E. (2015). Energy productivity, fertilization rate and profitability of wheat production after various predecessors I. Energy productivity of wheat. Agricultural science and technology, Vol. 7(4), 436-440.

Vermerris, W. \& Saballos, A. (2013). Genetic enhancement of sorghumfor biomass utilization. InGenomics of the Saccharinae; Paterson, A., Ed.; Springer: New York, NY, USA, Volume 11, pp. 391-425, ISBN 978-1-4419-5947-8.

Zahedi, M., Eshghizadeh, H.R. \& Mondani, F. (2014). Energy Use Efficiency and economical analysis in cotton production system in an Arid region: A case study for Isfahan Province. Iran. Inter. J. Energy Eco. and Poli., 4, 43-52.

Ziaei S.M., Mazloumzadeh, S.M. \& Jabbary M. (2015). A comparison of energy use and productivity of wheat and barley (case study). Journal of the Saudi Society of Agricultural Sciences 14, 19-25. 